УДК 640.41

B. Ф. Аоченко,

д. т. н., професор кафедри готельно-ресторанної справи,

Начіональний університет хариових технологій, м. Київ

ORCID ID: 0000-0003-1788-1599

О. Б. Шидловсъка,

к. т. н., дочент кафедри готельно-ресторанної справи,

Начіональний університет хариових технологій, м. Київ

ORCID ID: 0000-0001-5318-1835

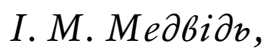

асистент кафедри готельно-ресторанної справи,

Начіональний університет хариових технологій, м. Київ

ORCID ID: 0000-0003-2537-2823

1. С. Бєдусенко,

магістрант кафедри готельно-ресторанної справи,

Начіональний університет хариових технологій, м. Київ

ORCID ID: 0000-0001-8346-7797

DOI: $10.32702 / 2306-6814.2020 .1 .51$

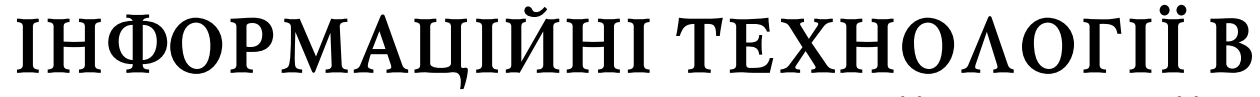 ГОТЕАЬНІЙ ІНАУСТРІЇ УКРӒ̈НИ: РЕААІЇ ТА ПЕРСПЕКТИВИ
}

\author{
V. Dotsenko, \\ Doctor of Technical Sciences, Professor of Department of Hotel and Restaurant Business, \\ National University of Food Technologies, Kyiv \\ O. Shydlovska, \\ $\mathrm{PhD}$ in Technical Sciences, Associate Professor of Department of Hotel and Restaurant Business, \\ National University of Food Technologies, Kyiv \\ I. Medvid, \\ Assistant Professor of Department of Hotel and Restaurant Business, \\ National University of Food Technologies, Kyiv \\ L. Biedusenko, \\ Master's degree student of Department of Hotel and Restaurant Business, \\ National University of Food Technologies, Kyiv
}

\section{INFORMATION TECHNOLOGIES IN UKRAINE'S HOTEL INDUSTRY: REALITIES AND PERSPECTIVES}

У статті проведено аналіз використання інформаційних технологій в готельному бізнесі України та розглянуто перспективи його розвитку. Висвітлено найбільш впливові аспекти функціонування індустрії гостинності. Обгрунтовано необхідність постійного впровадження інновацій на висококонкурентному ринку готельних послуг. Наведено причини низької інноваційної активності вітчизняних підприємств готельного господарства. Визначено, що перспективним напрямом розвитку готельного бізнесу є інформатизація засобів розміщення. Обгрунтовано доцільність впровадження інформаційних технологій (IT) як інноваційного напряму розвитку індустрії гостинності. Наведено приклади використання новацій у сфері інформаційних технологій у практичній діяльності провідних готелів світу, які визначають сучасність підприємств готельної індустрії та їх конкурентну спроможність. Виявлено, що з метою отримання конкурентних переваг на ринку готельних послуг актуальнимє використання інформаційних техно- 
логій для оптимізації менеджменту в готелі шляхом впровадження інтегрованих електронних систем управління. Звернуто увагу на необхідність застосування сервісних IT-технологій, до яких відносять глобальні системи бронювання та CRM системи. Окремо виділено доцільність автоматизації процесу комунікації відвідувачів з персоналом за допомогою мобільних додатків для обміну повідомленнями, що є передумовою покращення ефективності діяльності засобу розміщення. Встановлено актуальність впровадження інформаційних технологій в закладах ресторанного господарства при готелях. Визначено, що пріоритетним напрямом нововведень в цій сфері є використання інтерактивних технологій, які являють собою сенсорні столи або панелі з електронним меню. Розглянуто аргументи перспективності поєднання інтерактивних поверхонь з методом фудпейрингу, що сприятиме як зростанню економічного потенціалу підприємства гостинності, так і покращенню якості харчування споживачів. Загалом встановлено економічну доцільність впровадження інформаційних технологій на підприємствах готельного господарства, яка полягає в отриманні додаткового доходу, зниженні витрат, удосконаленні процесу обслуговування, забезпеченню конкурентних переваг на ринку, підвищенню ефективності роботи окремих підрозділів та готелю загалом.

The article analyzes the use of information technologies in the hotel business of Ukraine and considers the prospects for its development. The most influential aspects of the hospitality industry have been examined. The necessity of consistent implementation of innovations in the highly competitive hotel services market has been substantiated. The reasons for the low innovative activity of the domestic enterprises of the hotel industry have been given. Also, it has been determined that the forward-looking direction of hotel business development is informatization of lodging places. The expediency of the implementation of information technologies (IT) as an innovative trend in the development of the hospitality industry has been explained. The use of innovations in the area of information technologies has been illustrated on the basis of the world's leading hotels. Moreover, its importance for the modernity of the hotel industry enterprises and their competitiveness has been determined. On top of that, it has been proved that it is essential to use information technologies to optimize hotel management by implementing integrated electronic control systems in order to gain competitive advantages in the hotel services market. Special attention has been paid to the need for the use of service IT technologies including global reservation systems and CRM systems. The expediency of automating the process of visitor-to-staff communication using mobile messaging applications as a means for improving the efficiency of the lodging place functioning has been highlighted. The importance of the implementation of information technologies into hotels and restaurant facilities has been established. Furthermore, the use of interactive technologies such as touch tables or panels with electronic menus has been considered a top priority in the area of innovations. The arguments for the prospect of combining interactive surfaces with the method of foodpairing have been considered. It has been determined that the aforementioned interactive surfaces will contribute to both the increase of the economic potential of the hospitality enterprise and the improvement of the quality of consumers' nutrition. By and large, the economic feasibility of implementing information technologies in the hotel industry has been established, namely: it will provide additional income, reduce costs, improve rendered services, ensure competitive advantages in the market, increase the efficiency of individual units and the hotel in itself.

Ключові слова: інновачії, інновачійна діяльність, інформаційні технології, індустрія гостинності, готельний бізнес.

Key words: innovations, innovative activity, information technologies, hospitality industry, hotel business.

\section{ПОСТАНОВКА ПРОБАЕМИ}

Готельний бізнес $€$ одним з основних складових економіки України. В умовах сьогодення сорера готельного господарства, як і будь-яка інша, постійно трансфрормується під впливом глобалізації та інтеграції процесів. Так, ефективне фрункціонування індустрії гостинності $\epsilon$ індикатором позитивних змін в економіці держави, важливою передумовою інтенсифікації міжнародних зв'язків та інтеграції країни у світове співтовариство [1, с. 71]. Аналізуючи міжнародний досвід діяльності підприємств готельного бізнесу, можна зауважити, що зростання популярності цієї сфрери господарювання зу- 
мовлює підвищення жорсткості умов виживання, що змушує заклади постійно звертатися до розробок новітніх технологій задля збереження місця на ринку, боротьби за прихильність гостя, підвищення якості обслуговування, а також розширення асортименту надаваних послуг. Через велику кількість конкурентів кожному готелю слід мати власне обличчя та унікальну особливість, яка відрізняє його від інших. Тому інноваційний підхід до ведення бізнесу в даній сорері $€$ необхідною умовою для результативного функціонування підприємств готельного господарства. Впровадження інноваційних продуктів сприятиме ефективному використанню всіх можливостей якісного обслуговування та максимізації потенціалу діяльності закладів індустрії гостинності. Інноваційна діяльність $€$ важливим засобом, що забезпечує підтримку рівня конкурентоспроможності будь-якої економічної системи [2, с. 212; 3, с. 174].

Інноваційні розробки вітчизняних науковців та техніків користуються широкою популярністю за кордоном. Проте заклади готельного господарства України характеризуються низькою інноваційною активністю. На це впливає низка причин, серед яких як і економічні, так і політичні. Так, впровадження нововведень у вітчизняній практиці стикається з рядом гальмуючих фракторів, таких як ризик втрати капіталовкладень, відсутність досвіду з впровадження інновацій, відсутність стимулювання інновацій з боку держави, обмеженість у фінансових ресурсах підприємців, висока вартість інноваційних розробок та ін. [3, с. 176-177].

Саме тому наявність потужного потенціалу у сорері готельного бізнесу зумовлює актуальність проведення досліджень у цьому напрямі.

Використання нових технологій у розвитку виробництва або в управлінні підприємством дозволяє значно покращити його діяльність за рахунок передового досвіду, методів управління або наукових знань. Перевага в актуальності надається інформаційним технологіям, оскільки їх використання $€$ необхідною умовою функціонування будь-якого сучасного засобу розміщення або підприємства харчування, забезпечуючи точність, оперативність, високу швидкість обробки та передачі інформації.

\section{АНА $\Lambda$ IЗ ОСТАНHIX АОС $А$ ОЖЕНЬ І ПУБ $А$ КАЦІЙ}

Дослідження розвитку інформаційних технологій та впровадження їх на підприємствах готельного господарства відображено в наукових працях вітчизняних і закордонних науковців. Серед них можна зазначити роботи таких вітчизняних вчених: Мельниченко С.В., Миронов Ю.Б., Папирян Г.А., Пащута М.Т., Роглєв Х.Й., Скопень М.М. Важливі аспекти застосування інформаційних технології в галузях готельної сфери також відображено в працях європейських дослідників: Д. Бухаліса, У. Гретцель, М.Фукса.

Однак питання застосування інформаційних технологій в практичній діяльності підприємств гостинності потребує додаткових досліджень.

\section{META CTATTI}

Метою статті є систематизація досліджень щодо особливостей основних тенденцій впровадження інфор- маційних технологій у готельному господарстві, а також розроблення пропозицій щодо можливого їх застосування на підприємствах галузі.

\section{ВИКААА ОСНОВНОГО МАТЕРІААУ}

Готельний бізнес включає величезний комплекс послуг, а тому $є$ основним чинником у туристичній галузі i визначає перспективи її розвитку. Сьогодні міжнародний туризм продовжує неухильно зростати. Так, у 2018 р. у туристичному секторі світової економіки створено 10,4 \% глобального ВВП (8,8 трлн дол. США), а зайнятість населення планети у цій сорері становить $10 \%$, або 123 млн робочих місць. За майбутнім прогнозом ВВП зросте на 3,6 \%, в той час як сектори охорони здоров'я та гірничого видобутку зростуть лише на 2,3 \% та 1,5\% відповідно [4].

Аналіз діяльності готельного бізнесу в Україні згідно з даними Державної служби статистики показав, що у 2018 р. сума інвестиційних вкладень в сферу гостинності склала 2675 млн грн, що на $21 \%$ більше, ніж за 2017 р. Частка вкладень у засоби розміщення склала $55 \%$, а у заклади ресторанного господарства відповідно $45 \%$. Нараховано 61,8 тис. суб'єктів господарювання, що на 7 \% більше, ніж у 2017 р., і становить 3,35\% від загальної кількості зареєстрованих. Зайнятість у даній сфрері складає 1,7 \% від зайнятого населення, тобто 283 тис. осіб. Усього кількість засобів розміщення складає 4719 одиниць, які відвідало 7006,2 тис. туристів, з яких 917,9 тис. іноземні гості. Рентабельність закладів у 2018 р. становить 8,5 \%; для порівняння - у 2017 р. цей показник становив 7,8 \%, тоді як у 2016 р. $-0,8 \%$, тобто був збитковий [5].

Подальший розвиток готельного господарства в Україні передбачає не лише аналіз, а й планування та прогнозування діяльності на перспективу за відповідними етапами, починаючи з аналізу внутрішнього і зовнішнього середовища, визначення загальної стратегії функціонування підприємства з урахуванням сучасних вимог, виявлення власних можливостей і на їх основі побудови стратегії діяльності та розроблення концепції, бізнес-планів, програм і на завершення - процес реалізації проектів. Водночас розпочати варто з оновлення продукту, далі поліпшити техніко-економічний рівень послуг, їхні якість і конкурентоспроможність, а також звернути увагу на наукомісткість виробничої діяльності й експортоспроможність послуг.

Для забезпечення лідерства та отримання конкурентних переваг на ринку готельних послуг необхідним $€$ використання комп'ютерних мереж, Інтернет-технологій, наскрізної автоматизації всіх бізнес-процесів [6, c. 128].

Важко уявити сучасне функціонування підприємств індустрії гостинності без використання інформаційних технологій (IT). Застосування IT розповсюджується практично на всі види їх діяльності, як у здійсненні глобального управління, так і в координуванні щоденних процесів. Вона пов'язує всі види інформації, необхідної для управління на підприємстві і $є$ єдиною інфрормаційною системою.

Система управління і система інформації на будьякому рівні керування готелем утворює єдність. Управління без інформації $є$ неможливим. Інформація може 
включати в себе: дані про важливих людей, місця й об'єкти усередині організації або в навколишньому середовищі. Інфрормацією ми називаємо дані, перетворені в форму, яка $є$ корисною і придатна до використання. Одним з вагомих напрямів інформаційних систем, що найдинамічніше розвиваються, $є$ електронне бронювання, створення якого дозволило інтегрувати всю індустрію гостинності в єдине ціле.

Широке використання інформаційних технологій обробки та передачі інфрормації дозволяє створити сучасний та зручний продукт для підприємств готельного бізнесу, що спрямований не лише на збільшення прибутку, а й утримування конкурентних позицій на ринку та завоювання прихильності гостя.

Переважна більшість фахівців переконана, що жодне підприємство індустрії гостинності не може обійтися без застосування комп'ютерних систем. Перші готельні комп'ютерні системи з'явилися кілька десятків років тому, і за цей час пройшли великий шлях розвитку. В умовах сьогодення комп'ютерні системи охоплюють усі процеси функціонування готелю і його взаємин зі споживачами його послуг. Розвиток інформаційних технологій та їх значні функціональні можливості привели до появи цілком інтегрованих систем комп'ютерного управління готельними підприємствами. Нині широко використовуються системи, засновані на застосуванні мереж персональних комп'ютерів із розвиненим інтерфейсом. Такий інфрормаційний міст дозволяє обмінюватися управлінською і фінансовою інформацією. Сучасні системи дозволяють автоматизувати виконання щоденних задач персоналу і управління готелем. Водночас досягається взаємозв'язок між різними службами готелю, що значною мірою підвищує ефективність і дозволяє позбутися помилок. Керівництво одержує могутній інструмент контролю за станом готелю і фрінансових потоків, а можливості зловживань персоналом готелю скорочуються до мінімуму [7, с. 213-220].

У своїй роботі "eTourism: Information technology for strategic tourism management" профресор Дімітріос Бухаліс [8] наголошує на тому, що глобальна мережа Інтернет $є$ ключовою ланкою між туристичними установами, партнерами та клієнтами у спільному використанні інфрормації, що призвело до організації ділових переговорів на відстані. У його дослідженнях детально описано, в яких цілях та з якою метою може використовуватись програмне забезпечення в організаціях туристичного напряму діяльності. Зокрема, підприємства в своїй повсякденній роботі використовують набір прикладних програмних засобів з метою адміністрування та обробки інформації. Наприклад, програмні засоби для обслуговування клієнтів (англ. front-office software) виконують такий різновид робіт у такому розрізі як реєстрація, підтвердження виїзду, обробка запитів, оформлення замовлень, видача платежів на місці здійснення покупки (касовий термінал), продаж та купівля квитків на проїзд, бронювання туру, складання та планування розкладу. Такі програмні процеси можуть використовувати як постачальники тур послуг, підприємства харчування, екскурсійні фрірми, транспортні компанії, заклади дозвілля, так і глобальні системи бронювання, що забезпечують швидке і зручне бронювання квитків на транспорт, резервування місць у готелях, прокат авто- мобілів, обмін валюти, замовлення квитків на розважальні та спортивні програми тощо. Натомість, сукупність прикладних процесів, що реалізують внутрішню обробку даних (англ. back-office software) призначені для організаційних потреб і управлінських завдань, а саме планування дій та програмної реалізації, моніторингу, фінансового управління транзакціями і бухгалтерського обліку, нарахування заробітної плати, контролю за управлінням матеріально-технічними ресурсами, захисту даних від несанкціонованого доступу тощо. Зазвичай у своїх потребах таке програмне забезпечення використовують туристичні організації та асоціації, державні установи, організатори урочистих подій чи заходів та ін. На думку Д. Бухаліса, поєднання програмного front-office та back-office забезпечує точну, своєчасну та економічну обробку інфрормації у великому обсязі $[8$, с. $15-16]$.

Водночас необхідно зазначити, що поняття інфрормаційних технологій тісно пов'язане з інноваціями.

Прикладом інновацій в інформаційних технологіях готельних підприємств $€$ інтегровані електронні системи управління, через які керівництво і персонал підприємства забезпечується необхідною актуальною і правдивою інформацією про стан підприємства, а також надання можливості уповноваженим особам без перешкод здійснювати вплив на рівні виконавців, попри їх територіальну віддаленість [9].

Інформаційно-технологічні рішення чинять значний вплив на економічний успіх готельного підприємства.

Статистичні дані одного із світових виробників інноваційного програмного забезпечення для закладів готельного і ресторанного господарства Toast свідчать про те, що:

- $95 \%$ власників ресторанів відзначили підвищення ефрективності свого бізнесу, впровадивши програмні технології у діяльність підприємств;

- 73 \% відвідувачів вважають, що застосування сучасних технологій у закладі додає їм більше задоволення від вечері [10, с. 10];

- $26 \%$ споживачів вважають, що наявність сучасних технологій, можливість зробити електронне замовлення та обрати сучасні варіанти платежів впливають на вибір закладу [11].

В індустрії готельного господарства можна узагальнити декілька напрямків використання IT-технологій, а саме оптимізацію управління готелем, покращення сервісу і маркетинг.

До ІТ-технологій, які оптимізують менеджмент у готелі відносяться комп'ютерні системи центрального управління готелем, системи управління внутрішніми службами, які дозволяють ефективно обслуговувати гостей, технології оповіщення про готовність номерів, технологія замовлення їжі в ресторані. Найбільш поширеним універсальним продуктом $€$ комплекс найбільшої у світі компанії "Micros-Fidelio", що спеціалізується на створенні систем управління для готелів і ресторанів упродовж 20 років. Така система встановлена на підприємствах більше 100 найбільших готельних мереж (Sheraton, Hilton, Marriott, Kempinsky, Нyatt та ін.). Найбільшими комп'ютерними системами бронювання на міжнародному ринку туризму є системи Amadeus, Galileo, Sabre i Worldspan. Разом ці системи налічують 
близько 500 тис. терміналів, встановлених у готелях по всьому світу, що складає 90 \% ринку, невипадково їх називають "золотою четвіркою". 10 \% займають регіональні системи бронювання і системи, які знаходяться на стадії злиття з однією з вищевказаних систем [12].

В Україні системи представлені:

- PMS провідних світових виробників програмного забезпечення для готельної галузі - наприклад, Micros-Fidelio або Еpitome від SoftBrand;

- якісні розробки компаній з країн СНД, як-от: "Едельвейс", "Готель 2.3" ("Інтерготель"), Intellect Style. Як правило, вік таких продуктів - більше 15 років, і накопичений за цей період досвід втілився в "промисловий продукт";

- новачки - програмне забезпечення, що з'явилося в останні 3-5 років;

- HMS з Америки [13].

Сервісні IT-технології являють собоюглобальні системи бронювання та CRM системи. Глобальні системи бронювання дозволяють клієнту обрати для себе найзручніший варіант проживання, враховуючи всі переваги. Основою технології CRM $€$ накопичення інфрормації про клієнта і управління цими даними. Бази даних клієнтів дозволяють детально вивчати цільову аудиторію готелю, прогнозувати попит на послуги, проводити ефрективну маркетингову політику.

3 розвитком готельної індустрії та збільшенням кількості і різноманітності готелів їх відвідувачам стає важко зробити вибір, що є передумовою активного використання інтернет-маркетингу. Так, у боротьбі за клієнта у готелів все більше розвивається конкуренція, і щоб її виграти, необхідно бути в тренді і використовувати нові інформаційні технології. Інновації вважаються драйвером економічного зростання і джерелом конкурентної переваги компаній [14, с. 66].

Перспективним напрямком покращення ефективності діяльності засобу розміщення $є$ автоматизація процесів комунікації відвідувачів з персоналом. Такі великі готельні мережі, як Hyatt, Starwood, Marriott визнали зростаючу перевагу споживачів, які використовують мобільні додатки для обміну повідомленнями, та впровадили своїх чат-ботів в якості каналів зв'язку зі службою обслуговування клієнтів. Застосування такої технології дозволяє опрацьовувати до $90 \%$ запитів без втручання персоналу готелю і суттєво заощаджувати [15; 16]. Віртуальний консьєрж Edward з'явився в 12 готелях готельної мережі Radisson Blu у Великобританії. Він майже повністю розвантажив співробітників, в обов'язки яких входило листування з гостями. Edward може розповісти про послуги готелю, допомогти замовити обслуговування номеру, надати рекомендації туристу щодо вибору закладу ресторанного господарства та прийняти від клієнта скаргу [17].

Досить актуальним $є$ пошук нових прогресивних технологій та впровадження їх у закладах ресторанного господарства при готелях. Перспективними $є$ інтерактивні технології, оскільки їх особливості застосування передусім полягають у відсутності необхідності очікування офіціанта для оформлення замовлення, виключаючи помилки. Для цього на сенсорних панелях розміщується меню закладу з простою навігацією, що дозволяє не тільки отримати повну інформацію про страву, а також внести уточнення щодо її приготування, яке передається на виробництво. До використання також доступні сервіси погоди, соціальних мереж та ігор, кнопка виклику офріціанта і можливість розрахунку безконтактним способом.

Виділимо головні переваги впровадження інтерактивних технологій за фракторами:

- збільшення прибутку (збільшення середнього чека, кількості відвідувачів, скорочення витрат на залучення клієнтів за рахунок унікальності ресторану, відмова від друкованих меню та інших презентаційних матеріалів і т.д.);

- поліпшення сервісу (отримання в один дотик інформації про страву (склад, калорійність, рекомендовані напої), миттєве замовлення, управління атмосферою і т.д.);

- додатковий дохід (можливість збільшення середнього чека, новий фрормат ресторану, розміщення реклами і т.д.);

- операційна діяльність (ведення повного контролю, скорочення часу за рахунок того, що замовлення надходить на кухню та бар миттєво, збільшується швидкість обслуговування і т.д.).

Попри перспективність такої технології, в Україні станом на 01.12.2019 р. нараховується лише чотири заклади, з яких три у м. Львові, м. Одесі та м. Києві (мережа інтерактивних кафе Papashon), та у м. Києві - бар GoodWine.

За даними української компанії-розробника інтерактивних столів для закладів ресторанного господарства Kodisoft, їх термін окупності становить до 1 року, що пояснюється такими причинами:

- збільшення продажів на 32 \% шляхом продажу більшого обсягу страв та напоїв завдяки яскравому оформленню і представленню;

- скорочення витрат за рахунок залучення меншої кількості персоналу. Наприклад, для ресторану потужністю 100 місць у середньому потрібно 8-9 офріціантів, а в інтерактивних закладах - лише 2-3, що дозволяє надати гарний сервіс та досягти вищого економічного ефекту при меншій взаємодії. Це пояснюється тим, що на сучасному ринку конкурентна боротьба змушує заклади підвищувати якість обслуговування. Для порівняння, 15 років тому один незадоволений гість не міг вплинути на діяльність закладу, в той час як сьогодні навіть один негативний відгук може мати суттєві наслідки. А тому прихильність гостя з роками тільки набуває цінність [18].

Актуальність використання інтерактивних поверхонь полягає у тому, що вони являються зручним інструментом для створення нових інновацій.

Однією з таких пропозицій $є$ розміщення на інтерактивних столах меню, яке складається на основі технологіï Foodpairing, особливість якої полягає у підборі рецептурних інгредієнтів страв за схожими ароматичними сполуками. Програмним забезпеченням, яке працює на основі методу фудпейрінгу, $є$ Flavorstudio, математичний алгоритм якого використовується для виявлення поєднань ароматів з величезної бази даних. Ця база налічує понад 1 млн поєднань для заданих інгредієнтів [19, с. 60]. Сутність такої інновації полягає не лише у підборі харчових продуктів, а й у тому, що гото- 
ва страва компонується згідно принципів здорового харчування, тобто кількість і вага інгредієнтів вираховується системою так, щоб задовольнити основну добову потребу людини в мікро-та макронутрієнтах. Питання здорового і якісного харчування все частіше висвітлюється останні роки, тому сучасні технології мають бути спрямовані на поліпшення якості життя людини. Впровадження інтерактивних поверхонь у поєднанні з технологією Foodpairing у закладах ресторанного господарства при готелях приваблюватиме не лише туристів, а і місцевих жителів, що підвищить прогнозований економічний ефект від діяльності підприємства. Це $є$ важливим фактором, бо без отримання прибутку функціонування будь-якого закладу втрачає сенс.

\section{ВИСНОВКИ}

Таким чином, ключовою основою забезпечення конкурентоспроможності, динамічного розвитку та підвищення результативності функціонування підприємств готельного бізнесу в Україні $є$ впровадження інновацій. У результаті аналізу наукової літератури встановлено, що конкурентна перевага закладів готельного господарства залежить від нововведень в області інформаційних технологій. Тому, враховуючи набутий досвід та перспективи вітчизняних та зарубіжних дослідників у цій сорері, ІТ-технології є пріоритетним напрямом інноваційної діяльності об'єктів індустрії гостинності. Впровадження інформаційних технологій на підприємствах готельного господарства є економічно доцільним та ефективним, оскільки вони сприяють отриманню додаткового доходу та зниженню витрат, удосконаленню процесу обслуговування, забезпеченню конкурентних переваг на ринку, підвищенню ефективності роботи окремих підрозділів та готелю загалом.

\section{Література:}

1. Шаповалова О.М. Аналіз інноваційної діяльності у сфрері послуг на прикладі готельного господарства [Текст] / О.М. Шаповалова, С.С. Козьякова // Інвестиції: практика та досвід. - 2013. - № 17. - С. 70-74.

2. Шикіна О.В. Теоретичні основи діяльності концептуальних готелів та їх класифікація [Текст] / О.В. Шикіна, Г.І. Фадєєва // Східна Європа: економіка, бізнес та управління. - 2017. - Вип. 6 (11). - С. 212-219.

3. Коваленко Н.О. Інноваційні напрямки розвитку індустрії гостинності в Україні [Текст] / Н.О. Коваленко // Європейські перспективи. - 2015. - № 7. C. $174-179$.

4. About WTTC [Електронний ресурс] / World Travel \& Tourism Council: [сайт]. - Режим доступу: http:// www.wttc.org/research/economic-impact-research/ country-reports /

5. Статистичний щорічник України за 2018 рік [Електронний ресурс] / Державна служба статистики: [сайт]. - Режим доступу: https://ukrstat.org/uk/druk/ publicat/kat_u/publ1_u.htm

6. Ковальчук Т.Г. Перспективи розвитку готельноресторанного бізнесу в Україні в умовах глобалізації світового господарства [Текст] / Т.Г. Ковальчук // Науковий вісник Ужгородського національного університету: серія: Міжнародні економічні відносини та світове господарство. - 2019. - Вип. 23, Ч. 1. - С. 126-130.
7. Федосова К.С. Сучасні інформаційні технології у готельному і ресторанному бізнесі [Текст]: монографрія / К.С. Федосова, Л.М. Тележенко. - Одеса: ТЕС, 2010. -264 c.

8. Buhalis D. (2003), "eTourism: information technology for strategic tourism management", Pearson, London, UK. pp. $15-16$.

9. Останкова Е.С. Организация и управление деятельностью предприятия в режиме реального времени [Електронный ресурс] / Business process fusion: [сайт]. - Режим доступа: http://www.klubok.net/article1487.html

10. Restaurant Technology in 2017 [Електронний реcypc] / Toast: [сайт]. - Режим доступу: https:// pos.toasttab.com/resources/restaurant-technologyindustry-report

11. Restaurant Industry Factbook 2019 [Електронний pecypc] / National Restaurant Association: [сайт]. Режим доступу: https://restaurant.org/Downloads/ PDFs/Research/SOI/restaurant_industry_fact_sheet_2019.pdf

12. Рябенька М.О. Застосування новітніх інформаційних систем управління готелем [Електронний ресурс] / М.О. Рябенька, В.В. Троян, Т.М. Молодовець / / Матеріали конференції "Перспективные вопросы мировой науки": 17-25 грудня 2014 р. - Софрія, Болгарія: "Бял ГРАД-БГ" ООД, 2014. - Режим доступу: http:// tourlib.net/statti_ukr/ryabenka.htm

13. Гордієнко Т.В. Використання інформаційних систем в готельному господарстві Харківського регіону / Т.В. Гордієнко / / Менеджмент міського та регіонального розвитку: матеріали Міжнар. наук.-практ. конф., Харків, 28-29 березня. - Х.: ХНАМГ, 2013. С. $189-190$.

14. Халілова-ЧуваєваЮ.А. Сучасні тенденції розвитку IT-технологій у сорері готельного господарства [Текст] / Ю.А. Халілова-Чуваєва, Н.С. Сорокіна // Матеріали X Міжнародної науково-практичної конференції "Туристичний та готельно-ресторанний бізнес в Україні: проблеми розвитку та регулювання": $21-22$ березня 2019 р. - Черкаси: ЧДТУ, 2019. - Т. 1. - 195 с.

15. Chatbots for hotels: How can you best use them today? [Електронний ресурс] / Media Concepts: [сайт]. - Режим доступу: https://www.mediaconcepts.com / resources/chatbots_for_hotels.html

16. Боты, роботы и Rēvenue Management System: как отельный бизнес стал первоклассной digital-историей [Електронний ресурс] / Cossa: [сайт]. - Режим доступy: http://www.cossa.ru/trends/158514/href/

17. В отелях Radisson Blu появился консьерж-бот [Електронний ресурc] / Lenta. Путешествия: [сайт]. Режим доступу: https://lenta.ru/news/2016/05/13/ chatbot/

18. Ресторан майбутнього: українець Дмитро Костик створює глобальну мережу закладів з інтерактивними столами [Електронний ресурс] / Интернет-бизнес в Украине: [сайт]. - Режим доступу: https://ain.ua/ 2015/03/19/restoran-budushhego-ukrainec-dmitrijkostik-sozdaet-globalnuyu-set-zavedenij-s-interaktivnymi-stolami/

19. Коренець Ю.М. Питання продовольчого забезпечення людини в польових умовах [Текст] / Ю.М. Ко- 
ренець, Ю.В. Єріс, Ю.В. Зайченко // Обладнання та технології харчових виробництв. - 2017. - Вип. 35. C. $56-62$.

\section{References:}

1. Shapovalova, O.M. and Koz'iakova, S.S. (2013), "Analysis of innovative activities in the service sector of hotel business", Investytsii: praktyka ta dosvid, vol. 17, pp. $70-74$.

2. Shykina, O.V. and Fadieieva, H.I. (2017), "Theoretical bases of activity of conceptual hotels and their classification", Skhidna Yevropa: ekonomika, biznes ta upravlinnia, vol. 6 (11), pp. 212-219.

3. Kovalenko, N.O. (2015), "Innovative directions of development of hospitality industry in Ukraine", Yevropejs'ki perspektyvy, vol. 7, pp. 174-179.

4. The official site of World Travel \& Tourism Council (2019), "World Travel \& Tourism Council: Travel \& Tourism Benchmarking Reports 2019", available at: https:// www.wttc.org/-/media/files/reports/economicimpact-research/regions-2019/world2019.pdf (Accessed 26 November 2019).

5. The official site of State Statistics Service of Ukraine (2019), "Statistical Yearbook of Ukraine for 2018", available at: https://ukrstat.org/uk/druk/publicat/kat u/2019/zb/07/Ukr cifra 2018 u.pdf (Accessed 26 November 2019).

6. Koval'chuk, T.H. (2019), "Prospects for development of hotel and restaurant business in Ukraine in the conditions of globalization of the world economy", Naukovyj visnyk Uzhhorods'koho natsional'noho universytetu : seriia: Mizhnarodni ekonomichni vidnosyny ta svitove hospodarstvo, vol. 23, p.1, pp. 126-130.

7. Fedosova, K.S. and Telezhenko, L.M. (2010), Suchasni informatsijni tekhnolohii u hotel'nomu i restorannomu biznesi [Modern information technologies in the hotel and restaurant business], TES, Odesa, Ukraine.

8. Buhalis, D. (2013), "ETourism: information technology for strategic tourism management", Pearson, London, UK, pp. 15-16.

9. Ostankova, E.S. (2004), "Organization and management of the enterprise in real time", available at: http:/ /www.klubok.net/article1487.html (Accessed 26 November 2019).

10. The official site of Toast (2017), "Restaurant Technology in 2017", available at: https://pos.toasttab.com/ resources/restaurant-technology-industry-report (Accessed 26 November 2019).

11. The official site of National Restaurant Association (2019), "Restaurant Industry Factbook 2019", available at: https://restaurant.org/Downloads/PDFs/Research/ SOI/restaurant_industry_fact_sheet_2019.pdf (Accessed 26 November 2019).

12. Riaben'ka, M.O., Troian, V.V. and Molodovets', T.M. (2014), "Application of the innovative hotel management information systems", Materialy konferentsii "Perspektyvnye voprosy myrovoj nauky" [Conference Proceedings of the Conference "Perspective questions of world science"], Bial HRAD-BH OOD, Sofia, Bulgary, 17 25 December.

13. Hordiienko, T.V. (2013), "The use of information systems in the hotel industry of Kharkiv region", Zbirka dopovidej Mizhnarodnoi naukovo-praktychnoi konferentsii. Menedzhment mis'koho ta rehional'noho rozvytku [International scientific and practical conference Proceedings. Urban and regional development management], National University of Urban Economy, Kharkiv, Ukraine, 28-29 March, pp. 189-190.

14. Khalilova-Chuvaieva, Yu.A. and Corokina, N.S. (2019), "Modern tendencies of development of IT-technologies in the sphere of hotel managemen", Materialy $X$ Mizhnarodnoi naukovo-praktychnoi konferentsii "Turystychnyj ta hotel'no-restorannyj biznes v Ukraini: problemy rozvytku ta rehuliuvannia" [Proceedings of the $X$ International Scientific and Practical Conference "Tourism and hotel and restaurant business in Ukraine: problems of development and regulation"], State Technological University, Cherkasy, Ukraine, 21-22 March, p. 195.

15. The official site of Media Concepts (2016), "Chatbots for hotels: How can you best use them today?", available at: https://www.mediaconcepts.com /resources/ chatbots_for_hotels.html (Accessed 26 November 2019).

16. The official site of Cossa (2017), "Bots, robots and Revenue Management System: how the hotel business has become a first-class digital history", available at: http:// www.cossa.ru/trends/158514/href / (Accessed 26 November 2019).

17. The official site of Lenta (2016), "Concierge bot appears at Radisson Blu hotels", available at: https:// lenta.ru/news/2016/05/13/chatbot/ (Accessed 26 November 2019).

18. The official site of Internet business in Ukraine (2015), "Future Restaurant: Ukrainian Dmitro Kostyk creates a global network of restaurants with interactive tables", available at: https://ain.ua/2015/03/19/restoran-budushhegoukrainec-dmitrij-kostik-sozdaet-globalnuyu-set-zavedenij-sinteraktivnymi-stolami / (Accessed 26 November 2019).

19. Korenets', Yu.M. Yeris, Yu.V. and Zajchenko Yu.V. (2017), "Issues of human food supply in the field", Obladnannia ta tekhnolohii kharchovykh vyrobnytstv, vol. 35 , pp. $56-62$.

Стаття надійшла до редакцї 18.12.2019 p.

\section{www. economy.nayka.com.ua}

Електронне фахове видання

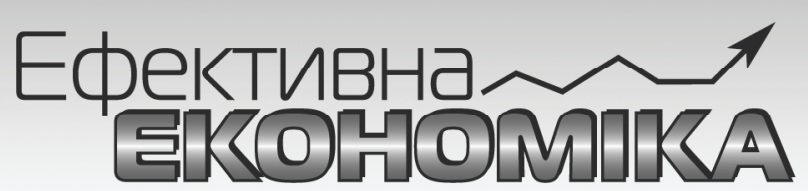

Виходить 12 разів на рік

Журнал включено до переліку наукових фахових видань України з ЕКОНОМІЧНИХ НАУК (Категорія «Б»)

Спеціальності - 051, 071, 072, 073, 075, 076, 292

e-mail:economy_2008@ukr.net

тел.: (044) 223-26-28

(044) $458-10-73$ 